\title{
A Novel Chimeric Endolysin with Antibacterial Activity against Methicillin-Resistant Staphylococcus aureus
}

OPEN ACCESS

Edited by:

D. Scott Merrell,

Uniformed Services University of the Health Sciences, United States

Reviewed by:

Gregory T. Robertson Colorado State University, United States

Neal D. Hammer,

Michigan State University,

United States

*Correspondence:

Rezvan Monir

moniri@kaums.ac.ir

hamedir2010@gmail.com

Received: 31 December 2016 Accepted: 14 June 2017 Published: 30 June 2017

Citation:

Haddad Kashani H, Fahimi H, Dasteh Goli Y and Moniri R (2017) A Novel Chimeric Endolysin with Antibacterial Activity against Methicillin-Resistant

Staphylococcus aureus.

Front. Cell. Infect. Microbiol. 7:290. doi: 10.3389/fcimb.2017.00290

\begin{abstract}
Hamed Haddad Kashani ${ }^{1}$, Hossein Fahimi ${ }^{2}$, Yasaman Dasteh Goli ${ }^{3}$ and Rezvan Moniri ${ }^{1 *}$
${ }^{1}$ Anatomical Sciences Research Center, Kashan University of Medical Sciences, Kashan, Iran, ${ }^{2}$ Department of Molecular and Cellular Sciences, Faculty of Advanced Sciences and Technology, Pharmaceutical Sciences Branch, Islamic Azad University, Tehran, Iran, ${ }^{3}$ Department of Biology, University of Maryland, College Park, MD, United States
\end{abstract}

Cysteine/histidine-dependent amidohydrolase/peptidase (CHAP) and amidase are known as catalytic domains of the bacteriophage-derived endolysin LysK and were previously reported to show lytic activity against methicillin-resistant Staphylococcus aureus (MRSA). In the current study, the in silico design and analysis of chimeric CHAP-amidase model was applied to enhance the stability and solubility of protein, which was achieved through improving the properties of primary, secondary and tertiary structures. The coding gene sequence of the chimeric CHAP-amidase was synthesized and subcloned into the pET-22(+) expression vector, and the recombinant protein was expressed in E. coli BL21 (DE3) strain. Subsequent affinity-based purification yielded $\sim 12 \mathrm{mg}$ soluble protein per liter of $E$. coli culture. Statistical analysis indicated that concentrations of $\geq 1 \mu \mathrm{g} / \mathrm{mL}$ of the purified protein have significant antibacterial activity against $S$. aureus $\mathrm{MRSA}_{252}$ cells. The engineered chimeric CHAP-amidase exhibited 3.2 log reduction of $\mathrm{MRSA}_{252}$ cell counts at the concentration of $10 \mu \mathrm{g} / \mathrm{mL}$. A synergistic interaction between CHAP-amidase and vancomycin was detected by using checkerboard assay and calculating the fractional inhibitory concentration (FIC) index. This synergistic effect was shown by 8-fold reduction in the minimum inhibitory concentration of vancomycin. The chimeric CHAP-amidase displayed strong antibacterial activity against S. aureus, S. epidermidis, and enterococcus. However, it did not indicate any significant antibacterial activity against $E$. coli and Lactococcus lactis. Taken together, these findings suggest that our chimeric CHAP-amidase might represent potential to be used for the development of efficient antibacterial therapies targeting MRSA and certain Gram-positive bacteria.

Keywords: Staphylococcus aureus, endolysin, antibacterial agent, CHAP-amidase domain, in silico analysis, antibiotic resistant, synergistic

\section{INTRODUCTION}

Over the recent years, resistance to antimicrobial drugs has become a growing global concern. This health problem is rooted in the fact that antibiotic-based treatment of many infectious diseases has led to the emergence of multi-resistant strains of bacteria (Pogue et al., 2015). The rise of these multi-drug resistant bacterial strains highlights the need to develop new antimicrobial compounds (Magiorakos et al., 2012). 
Staphylococcus aureus is known as one of the most significant infectious bacterial agents worldwide. The strains of this bacterium that have acquired methicillin resistance, also called MRSA, are considered a serious threat to human health (Reich et al., 2016).

Different species of the genus Staphylococcus are recognized as major pathogens for both human and various animals (De Lencastre et al., 2007). These bacteria are responsible for a wide variety of diseases, including skin and ocular infections, food poisoning, pneumonia, meningitis, endocarditis, and osteomyelitis (Nickerson et al., 2009; Bassetti et al., 2014). A considerable body of evidence has revealed that MRSA infection remains one of the main causes of hospital infections, leading to increasing rates of morbidity and mortality (Salge et al., 2016).

Bacteriophage endolysins are an important source of antimicrobial enzymes with peptidoglycan hydrolase activity. These antimicrobial agents, when applied exogenously in the form of purified recombinant proteins, can induce rapid lysis and death of Gram-positive bacterial cells (Jun et al., 2013). Phage-derived lysins represent potential use to target specific pathogenic bacteria, while not influencing the body's normal microbiota. A variety of investigations have discovered a broad range of lysins produced by different bacteriophages that can act specifically on certain host bacteria (O'flaherty et al., 2005; Hosseini et al., 2016; Schmelcher and Loessner, 2016). Previous studies have identified endopeptidase and amidase enzymes as potential therapeutics against a number of Gram-positive pathogens involved in triggering mucosal and systemic infections (Nelson et al., 2001; Schuch et al., 2002; Entenza et al., 2005; McCullers et al., 2007; Rashel et al., 2007; Daniel et al., 2010). As opposed to antibiotics, bacterial strains do not develop resistance to phage lysins (Loessner, 2005). These lysins target specific molecules in the host peptidoglycan that are required for cell viability (Fischetti, 2010). Staphylococcus aureus phage lysins, such as LysK, MV-L, phi11, and LysH5, possess a multi-domain structure composed of a C-terminal cell wall binding domain and two N-terminal catalytic domains (Donovan et al., 2006; Obeso et al., 2008). C-terminal domain has been reported to be required for lytic activities of endolysin (Loessner et al., 2002; Sass and Bierbaum, 2007). The majority of lysins bind to specific substrates in the bacterial cell wall through non-covalent carbohydrate bonds (Loessner et al., 2002; Nelson et al., 2006; Oliveira et al., 2016). The native lysins of $S$. aureus, except for MV-L, inherently display low expression yields, insolubility, and poor activity when generated in vitro (Fenton et al., 2010).

A number of studies have demonstrated the increased lytic activity of several enzymes upon deletion of their binding domains (Cheng et al., 1994; Cheng and Fischetti, 2007; Horgan et al., 2009). Compared with native enzyme, the truncated $\mathrm{N}$-terminal endopeptidase domain, also known as CHAP (cysteine, histidine-dependent amidohydrolase/peptidase), of LysK indicates significantly higher levels of antibacterial lytic activity (Horgan et al., 2009). Once the C-terminal binding domain of native enzyme is bound to its target molecule in the bacterial cell wall, the function of $\mathrm{N}$-terminal lytic domain may be altered, leading to inhibition of the potential activity of lytic domain (Low et al., 2005; Briers et al., 2009). LysK proteins containing CHAP and amidase domains have been reported to exhibit lytic activity against MRSA strains (Becker et al., 2009). Previous studies have shown that the recombinant production of LysK protein in E. coli may result in the formation of insoluble inclusion bodies, possibly due to the adverse formation of disulfide bonds in the protein (Ventura and Villaverde, 2006; Yoon et al., 2010). Proteolytic degradation and protein misfolding are common problems in the expression of recombinant proteins in bacterial cells. These difficulties are frequently encountered, especially if the protein is insoluble and cytoplasmic. To surmount such obstacles, recombinant proteins can be targeted to the periplasmic space via the activity of signal sequences like PelB (Low et al., 2013). It is also of interest to note that formation of inclusion bodies in E. coli seems to be a universal problem associated with overexpression of heterologous proteins (Rinas et al., 2007; Martínez-Alonso et al., 2009).

pET-22b is a family of pET vectors providing an N-terminal pelB leader signal, which directs the secretion of expressed polypeptides to the E. coli periplasmic space (Yoon et al., 2010). The periplasmic space of $E$. coli cells harbors oxidoreductive enzymes, which play important roles in preventing the formation of disulfide bonds and inclusion bodies (Berkmen, 2012). The in silico analysis of CHAP-amidase has provided valuable insights into the structure and function of lysins (Fenton et al., 2011a). This information can be used for the design and selection of essential parts of CHAP-amidase to assess its antibacterial activity against $\mathrm{MRSA}_{252}$ strain.

Here, we report the in silico design and analysis, expression, purification, and subsequent characterization of the antibacterial activity of a chimeric endolysin against MRSA $_{252}$ bacterial cells. We evaluated the activity of chimeric endolysin in various conditions and observed its synergistic activity when combined with vancomycin. In addition, we examined the antibacterial effects of chimeric CHAP-amidase against other bacterial strains, including S. aureus, S. epidermidis, E. faecium, E. faecalis, E. coli, and L. lactis.

\section{MATERIALS AND METHODS}

\section{Construction and Analysis of Chimeric CHAP-Amidase}

Prior to synthesis of the sequence encoding chimeric CHAPamidase, the sequence was optimized by Gen Script codon optimization software (http://www.genscript.com/).

The sequence of LysK was obtained from GenBank database (Accession No: AFN3871, www.ncbi.nlm.nih.gov/genbank/). The chimeric protein consists of the N-terminal CHAP domain (amino acids 38-164) fused to the C-terminal amidase-2 domain (amino acids 210-334) of LysK (Supplementary Figure 1). The two domains were connected by a decapeptide linker (GSHHHHHHGS), which also served as an internal His-tag for affinity purification. The designed amino acid sequence was analyzed using the Basic Local Alignment Search Tool (BLAST) (http://blast.ncbi.nlm.nih.gov/Blast.cgi). The Protparam (http:// web.expasy.org/protparam/) and HMMTOP servers (www. enzim.hu/hmmtop) were used to investigate the primary structure properties and to predict trans-membrane helices, 
respectively. Secondary structures were predicted using Chou and Fasman method (http://cho-fas.sourceforge.net/index.php). Tertiary structures were modeled in PDB format via I-TASSER server (Zhang, 2008; Roy et al., 2010; Yang and Zhang, 2015; Yang et al., 2015). The constructed structural models were analyzed by PyMol software. For model stability studies, 3D PDB models were subjected to evaluation by Ramachandran plot analysis (RAMPAGE software) (Lovell et al., 2003) and PDBsum server (http://www.ebi.ac.uk/thornton-srv/databases/pdbsum).

\section{Docking of Protein-Ligand Binding}

The interaction of CHAP-amidase protein with cysteine, glycerol and piperazine ligands was analyzed by HEX 6.3 software, which allows to predict the free energy of binding (Ritchie and Venkatraman, 2010).

\section{Design and Synthesis of the Coding Gene Fragment}

The gene sequence was optimized in terms of codon usage and GC content for optimal expression in E. coli by using the webbased server optimizer (http://genomes.urv.cat/OPTIMIZER/). The restriction sites for HindIII and NcoI enzymes were located at $3^{\prime}$ and $5^{\prime}$ sites of the coding sequence, respectively. The designed gene was synthesized by MWG-Biotech (Ebersberg, Germany) and incorporated into a pEX backbone.

\section{Bacterial Culture, Subcloning, and Protein Expression}

The E. coli strain BL21 (DE3) (Invitrogen, Carlsbad, CA) was grown at $37^{\circ} \mathrm{C}$ in Luria-Bertani (LB) medium (Rosano and Ceccarelli, 2014). The LB medium was then supplemented with ampicillin $(100 \mu \mathrm{g} / \mathrm{mL})$ for plasmid selection. The subcloning of CHAP-amidase-encoding sequence into plasmid and transformation of $\mathrm{pEX}$ and $\mathrm{pET}-22 \mathrm{~b}$ (Novagen, USA) vectors into bacterial cells were followed by standard restriction enzyme digestion and sequence analysis, which were used to verify the cloning procedure.

Protein expression was performed in BL21 (DE3) strain as previously reported (Kashani and Moniri, 2015; Hosseini et al., 2016). Briefly, the recombinant pET-22b plasmid was transformed into bacterial cells and the cells were cultured in LB medium containing $100 \mu \mathrm{g} / \mathrm{mL}$ of ampicillin. The culture was further incubated at $37^{\circ} \mathrm{C}$ and protein expression was induced by addition of isopropyl $\beta$-D-1-thiogalactopyranoside (IPTG) to the final concentration of $1 \mathrm{mM}$ at logarithmic phase (corresponding to $\left.0.5-0.6 \mathrm{OD}_{590}\right)$. Cells were harvested after $4 \mathrm{~h}$ and protein expression was evaluated by SDS-PAGE (sodium-dodecyl sulfate polyacrylamide gel electrophoresis).

\section{Western Blot Analysis}

Western blot analysis was conducted as previously reported (Fahimi et al., 2014; Ferdosian et al., 2015; Hosseini et al., 2016). Briefly, the lysate of CHAP-amidase-expressing cells was run on 10\% SDS-PAGE (Bioneer Co., South Korea) and transferred onto nitrocellulose membrane using a semi-dry transfer system. The membrane was blocked overnight in 5\% skimmed milk at $4^{\circ} \mathrm{C}$ and then incubated with primary antibody (anti-His tag monoclonal antibody (mAb) (Abcam Inc., MA, USA), while shaking for $2 \mathrm{~h}$ at room temperature $\left(22^{\circ} \mathrm{C}\right)$. The membrane was washed three times with PBST (PBS containing 0.05\% Tween 20) and incubated with secondary antibody (1:4,000 dilution of HRP-conjugated rabbit anti-mouse IgG antibody) (Abcam Inc., MA, USA) with gentle shaking for $1 \mathrm{~h}$ at room temperature. The membrane was washed three times with PBST and the signal was detected by adding DAB ( $3,3^{\prime}$-diaminobenzidine) as a chromogenic substrate.

\section{Protein Purification}

The recombinant expression cultures of BL21 were harvested by centrifugation and the pellets were lysed via sonication. By using the modified nickel-chromatography Ni-NTA purification system (Qiagen, Valencia, CA), his-tagged proteins were separated according to the manufacturer's instructions. Briefly, Ni-NTA column was washed in two consecutive steps with 20 $\mathrm{mL} / 20 \mathrm{mM}$ and $10 \mathrm{~mL} / 10 \mathrm{mM}$ and then eluted with $0.5 \mathrm{~mL}$ of $250 \mathrm{mM}$ imidazole in the same phosphate-buffered saline (PBS) (300 mM NaCl, $50 \mathrm{mM} \mathrm{NaH2PO3,} \mathrm{pH} \mathrm{8)} \mathrm{using} \mathrm{30 \%}$ glycerol. Then, the samples were transferred into a buffer with low salinity (10 mM Tris- $\mathrm{HCl}, 150 \mathrm{mM} \mathrm{NaCl}, 1 \%$ glycerol; $\mathrm{pH}$ 7.5) by Zeba Desalting column (Thermo Fisher Scientific Inc., USA) and sterilized with $0.22 \mu \mathrm{m}$ filters and equilibrated in $2 \mathrm{X}$ PBS buffer. The concentration of purified protein determined by spectrophotometry using the Bradford assay (Achberger et al., 2011).

\section{Characterization of Antibacterial Activity against Methicillin-Resistant $S$. aureus}

The lytic effects of CHAP-amidase were investigated on methicillin-resistant Staphylococcus aureus strain (MRSA 252 ). The bacterial strain was purchased from ATCC and cultured in mannitol salt agar (MSA) medium.

\section{Disk Diffusion Assay}

The purified protein was diluted in saline Tris lysis buffer (STB), containing $150 \mathrm{mM} \mathrm{NaCl}$ and $10 \mathrm{mM}$ Tris- $\mathrm{HCl}(\mathrm{pH} \mathrm{7.5)}$, to the final concentrations of $10,1,0.5$, and $0.1 \mathrm{mg} / \mathrm{mL}$. Afterwards, a sterile $6 \mathrm{~mm}$ filter paper disk was used per concentration of CHAP-amidase. The saturated disks were spotted onto a freshly spread MRSA culture, while control disk was soaked in STB (Kusuma and Kokai-Kun, 2005; Becker et al., 2009; Jalali et al., 2016). The culture was incubated for $20 \mathrm{~h}$ at $37^{\circ} \mathrm{C}$.

\section{Specific Activity of CHAP-Amidase Endolysin}

To study the thermal stability of CHAP-amidase, the protein was pretreated under a range of temperatures from 5 to $60^{\circ} \mathrm{C}$. The protein stability was also evaluated at $-20^{\circ} \mathrm{C}, 4^{\circ} \mathrm{C}$, and $37^{\circ} \mathrm{C}$. The specific activity of CHAP-amidase against $\mathrm{MRSA}_{252}$ was determined by spectrophotometry (Eppendorf, Germany) at wavelength of $590 \mathrm{~nm}$ for $15 \mathrm{~min}$ and the number of bacterial colonies were evaluated by colony count assay (Fenton et al., 2011b).

To evaluate the specific activity of CHAP-amidase in different $\mathrm{pH}$ values, $\mathrm{MRSA}_{252}$ cells were resuspended in sodium acetate buffer $(50 \mathrm{mmol} / \mathrm{L})$ with $\mathrm{pH}$ values ranging from 4 to 12 . 
$100 \mu \mathrm{L}(1 \mu \mathrm{g} / \mathrm{mL})$ of CHAP-amidase was added to cells $(8 \times$ $\left.10^{8} \mathrm{CFU} / \mathrm{mL}\right)$ and $\mathrm{OD}_{590 \mathrm{~nm}}$ was monitored at $37^{\circ} \mathrm{C}$ for $15 \mathrm{~min}$ (Fenton et al., 2011b). The final enzyme concentration in each sample was $1 \mu \mathrm{g} / \mathrm{mL}$.

The tolerability of CHAP-amidase in different concentrations of $\mathrm{NaCl}$ was measured in mid-log phase cultures $\left(\mathrm{OD}_{590 \mathrm{~nm}} \sim 0.6\right.$ ) of $\mathrm{MRSA}_{252}$ cells. Sodium acetate buffer $(50 \mathrm{mmol} / \mathrm{L} ; \mathrm{pH} 7.5)$ was prepared containing various concentrations of $\mathrm{NaCl}$ from 0 to $700 \mathrm{mmol} / \mathrm{L} .100 \mu \mathrm{L}$ of cell solution incubated with $100 \mu \mathrm{l}$ of CHAP-amidase $(10 \mu \mathrm{g} / \mathrm{mL})$ was examined at $590 \mathrm{~nm}$ for $30 \mathrm{~min}$ and finally changes in colony forming unit (CFU) values were monitored.

\section{Antibacterial Activity of Different Concentrations of Endolysin on MRSA}

By growing mid-log phase cultures $\left(\mathrm{OD}_{590 \mathrm{~nm}} \sim 0.5-0.6\right)$ in Mueller-Hinton broth $(\mathrm{MHB})\left(37^{\circ} \mathrm{C}\right)$, freshly grown $\mathrm{MRSA}_{252}$ cells were obtained and then harvested by centrifugation $\left(4^{\circ} \mathrm{C}\right)$. Cells were recovered using $1 / 2$ volumes of a phosphate buffer, containing $250 \mathrm{mM} \mathrm{NaCl}$ and $25 \mathrm{mM}$ phosphate- $\mathrm{Na}(\mathrm{pH}$ 7.5). Subsequently, various concentrations of chimeric CHAPamidase $(10,5,1$, and $0.5, \mu \mathrm{g} / \mathrm{mL})$ were added to $1 \mathrm{~mL}$ cell suspensions. $\mathrm{OD}_{590 \mathrm{~nm}}$ was recorded for $1 \mathrm{~h}$ with 5 -min intervals. The colony forming unit $(\mathrm{CFU} / \mathrm{mL})$ was calculated at the end of each assay. The buffer without endolysin was used as negative control (Becker et al., 2009; Fernandes et al., 2012; Proença et al., 2012).

\section{Synergistic Interaction of CHAP-Amidase with Vancomycin}

The interaction between CHAP-amidase and vancomycin (Sigma-Aldrich) was assessed by standard checkerboard broth microdilution assay (Odds, 2003; Anju et al., 2015; Magi et al., 2015). Briefly, a 2-fold dilution of antibiotic and CHAP-amidase (in a final volume of $50 \mu \mathrm{L}$ ) was incubated vertically and horizontally, respectively, with a bacterial inoculum of $5 \times 10^{5}$ CFU per well. MRSA 252 strain was used to test the interaction between endolysin and vancomycin. The plates were incubated at $37^{\circ} \mathrm{C}$ with gentle shaking and the bacterial growth rate was determined by reading $\mathrm{OD}_{590 \mathrm{~nm}}$ for $20 \mathrm{~h}$. The fractional inhibitory concentration (FIC) of antibiotic and CHAP-amidase was calculated and plotted as an isobologram. The calculation of FIC index $(\Sigma)$ was performed according to the following formula: $\mathrm{FIC}=\mathrm{MIC}$ (in combination with CHAP-amidase)/MIC (alone)
$=>(\mathrm{FICA}=\mathrm{MICA}+\mathrm{B} / \mathrm{MICA}, \mathrm{FICB}=\mathrm{MICB}+\mathrm{A} / \mathrm{MICB}, \Sigma \mathrm{FIC}$ $=$ FICA + FICB). Synergism is defined as a $\Sigma$ FIC of $\leq 0.5$.

\section{Lytic Activity of CHAP-Amidase Endolysin against Other Bacterial Strains}

The activity of the three isolates of methicillin-resistant Staphylococcus, one isolate of methicillin-susceptible Staphylococcus, two isolates of vancomycin-resistant Enterococcus, one isolate of multi-drug resistant E. coli, and also Lactococcus lactis as a well-known genus of probiotic bacteria was measured in response to the chimeric endolysin by turbidity reduction assay and colony counting (Table 1). 10 $\mu \mathrm{g} / \mathrm{mL}$ of $\mathrm{CHAP}$-amidase was added to different microtubes of bacterial cultures and incubated at $37^{\circ} \mathrm{C}$ for $15 \mathrm{~min}$. Colony count assay was carried out to determine whether turbidity reduction is due to bacterial cell death.

\section{Statistical Analysis}

One-way analysis of variance (ANOVA) and Tukey's post-hoc test were employed to study differences between the five groups. $P<0.05$ were considered statistically significant. All statistical analyses were done using the Statistical Package for Social Science version 19 (SPSS Inc., Chicago, Illinois, USA). The values of experiments are the means of three independent experiments with indication of standard deviation (SD) (Kashani et al., 2013; Sharif et al., 2016, 2017).

\section{RESULTS}

\section{In silico Analysis of LysK (CHAP-Amidase) Codon Optimization}

The codon adaptation index (CAI) of chimeric CHAP-amidase was initially 0.68 , which is considered a weak expression index, but reached 0.88 after being optimized by Gen Scripts Optimum Gene software. There is a positive correlation between the possibility of high protein expression level and the value of CAI. A CAI of 1.0 is described as ideal and a CAI of $\geq 0.8$ is considered as appropriate for expression in the host organism. Moreover, GC content was first $36.11 \%$, which was changed into $52.33 \%$ following optimization (Supplementary Figure 2). It means that the codon usage of the gene is required to have a relatively higher GC content so that chimeric LysK could be expressed well in BL21 strain.

TABLE 1 | Bacterial species evaluated for sensitivity to CHAP-amidase.

\begin{tabular}{llll}
\hline Species & Strain & Description & Isolation \\
\hline Staphylococcus aureus & $\mathrm{MRSA}_{252}$ & Methicillin resistant (ATCC BAA-1720) & Hospital acquired \\
Staphylococcus aureus & $\mathrm{USA}_{300}$ & Methicillin resistant (ATCC BAA-1556) & HIV+ Patient \\
Staphylococcus aureus & $\mathrm{MSSA}_{476}$ & Methicillin susceptible (ATCC BAA-1721) & Hyper virulent community \\
Staphylococcus epidermidis & $\mathrm{CCF}_{15990}$ & Methicillin resistant (ATCC 51625) & Human blood \\
Entrococcus faecalis & $\mathrm{AGR}_{329}$ & Vancomycin resistant (ATCC BAA-2128) & Piglet feces \\
Entrococcus faecium & - & Vancomycin resistant (ATCC BAA-2317) & Human feces \\
Escherichia coli & $\mathrm{NDM}_{1}$ & Multi-drug resistant (ATCC BAA-2452) & Pakistan \\
Lactococcus Lactis & $\mathrm{NZ}_{9000}$ & Probiotic (VS-ELS09000-01) & MoBitec, Germany
\end{tabular}




\section{Sequence Analysis of CHAP-Amidase Protein}

It has been revealed that $\mathrm{CHAP}$ and amidase [peptidoglycan recognition protein (PGRP) superfamily] domains show antibacterial activity against Staphylococcus aureus (Becker et al., 2009; Horgan et al., 2009). The sequence of CHAP-amidase protein starts from an $\mathrm{N}$-terminal domain of CHAP (amino acids $38-164$ of the original sequence) that is fused to amidase domain (amino acids 210-334 of the original sequence) via a $6 \mathrm{x}$-His tag flanked by glycine and serine (GSHHHHHHGS). The amino acid sequence of chimeric protein starts with methionine and ends with histidine as shown in Figures 1A,D. The BLAST analysis of the designed amino acid sequence led to the recognition of two catalytic CHAP and amidase domains, which are members of NLPC/P60 and PGRP super families, respectively (Figure 1B).

According to the primary structure analysis of CHAP-amidase fusion protein, isoelectric point (pI) and instability index (II) were computed 6.73 and 30.94 , respectively. These computations identify CAHP-amidase fusion as a stable protein in bacteria. No transmembrane helix was detected by HMMTOP server. The protein secondary structure was predicted by Chou and Fasman method. As depicted in Figure 1C, CHAP-amidase protein consists of mostly alpha-helix and beta-sheet regions separated by turns and coils. The designed linker introduces a coil into the structure (residues 127-136).
To study the tertiary structure of CHAP-amidase protein, ITASSER server was used to construct 3-dimensional structural models in PDB format. As illustrated in Figure 2, functional and structural domains were predicted to be folded independently and linked together via a GS/6xHis/GS linker.

For model stability studies, 3D models were examined by Ramachandran plot analysis (Figure 3). More than 90\% of residues are identified in most favored and stericallyallowed regions. These features reflect the high sustainability of constructed models.

\section{Molecular Docking of Chimeric CHAP-Amidase}

In the current study, the binding energy of cysteine, glycerol and piperazine to the protein (PDB accession code 4ct3) was estimated to be $-150.67 \mathrm{~kJ} / \mathrm{mol},-129.83 \mathrm{~kJ} / \mathrm{mol}$, and $-228.66 \mathrm{~kJ} / \mathrm{mol}$, respectively (Figure 4). This finding suggests that interaction between CHAP-amidase and piperazine may be more potent than that of other ligands.

\section{Subcloning of the Synthesized Gene Sequence}

Subcloning of the sequence encoding CHAP-amidase was analyzed first by double digestion of pET-22 vector and running DNA fragments on agarose gel. The detection of

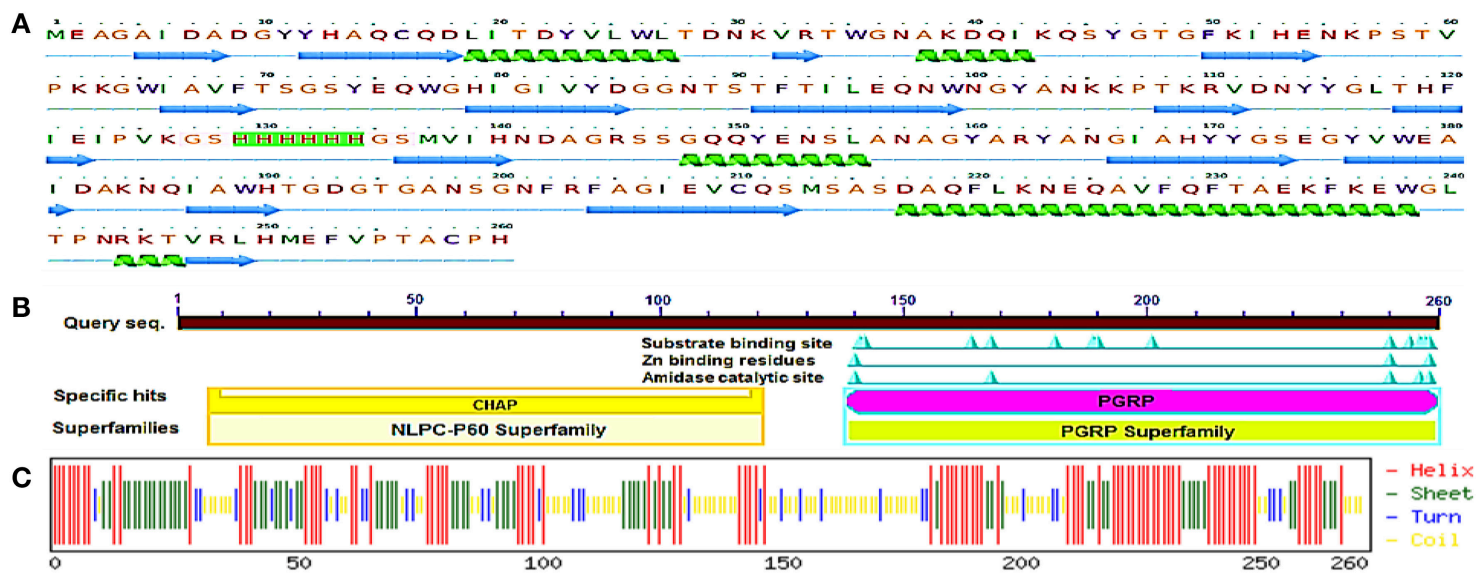

D Native Protein: AFN38718.1; LysK [Staphylococcus phage MSA6]

MAKTQAEINKRLDAYAKGTVDSPYRVKKATSYDPSFGVMEAGAIDADGYYHAQCQDLITDYVLWLTDNKV RTWGNAKDQIKQSYGTGEKIHENKPSTVPKKGWIAVFTSGSYEQWGH IGIVYDGGNTSTET ILEQNWNGY ANKKPTKRVDNYYGLTHEIEIPVKAGTTVKKETAKKSASKTPAPKKKATLKVSKNHINYTMDKRGKKPEG MVIHNDAGRSSGQQYENSLANAGYARYANGIAHYYGSEGYVWEAIDAKNQIAWHTGDGTGANSGNFREAG IEVCQSMSASDAQFLKNEQAVEQFTAEKFKEWGLT PNRKTVRLHMEFVPTACPHRSMVLHTGFNPVTQGR PSQA IMNKLKDYFIKQIKNYMDKGTSSSTVVKDGKTSSASTPATRPVTGSWKKNQYGTWYKPENATEVNG NQPIVTRIGSPELNAPVGGNLPAGATIVYDEVCIQAGHIWIGYNAYNGNRVYCPVRTCQGVPPNQIPGVA WGVEK.

Yellow: CHAP domain

Blue: Amidase domain

FIGURE 1 | The designed "CHAP-amidase" protein properties. (A) The amino acid sequence of the designed LysK/CHAP-amidase protein consists of N-terminal CHAP domain, GS-His tag linker, and C-terminal amidase domain. The linker sequence is highlighted in pink for GS and green for $6 x-H i s$ tag. The secondary structure of CHAP-amidase protein was analyzed by Phyre2 software and is displayed below the sequence as alpha helix (18\%) and beta strand (32\%) structures (Kelley et al., 2015). (B) According to the BLAST analysis of the LysK amino acid sequence, two catalytic CHAP (yellow) and amidase (purple) domains were recognized. (C) The predicted secondary structure of CHAP-amidase protein; the statistics are as follows: total residues: H (helix): 137, E (beta sheet): 89 , T (turn): 37 , and the frequency of structures: H: 52.7, E: 34.2, T: 14.2. (D) The native amino acid sequence of LysK containing 495 amino acids. 


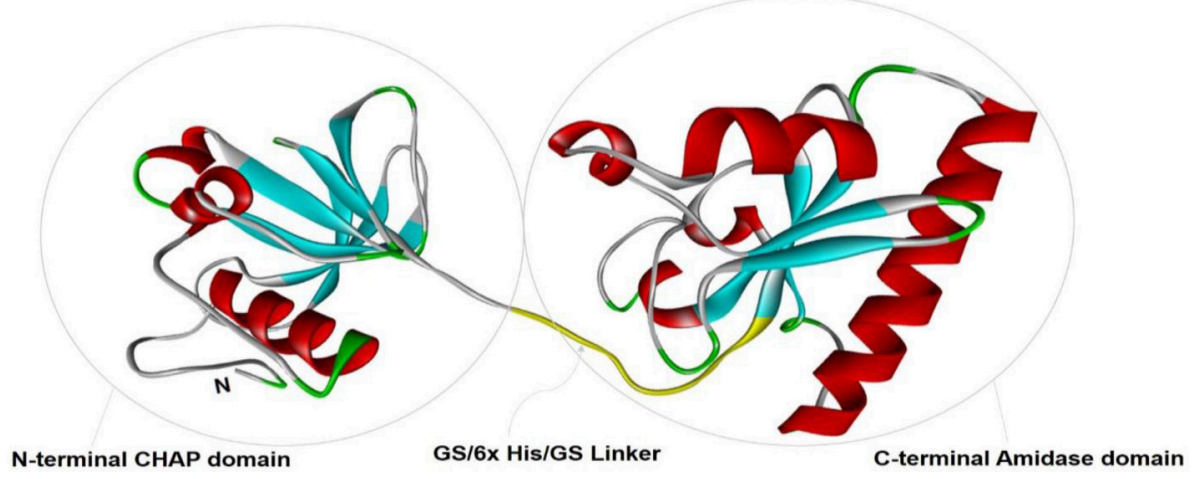

FIGURE 2 | The tertiary structural model of CHAP-amidase protein was visualized by Pymol software. Two functional and structural domains (CHAP and amidase domains) were predicted for independent folding. These domains were linked together via a GS/6xHis/GS sequence.
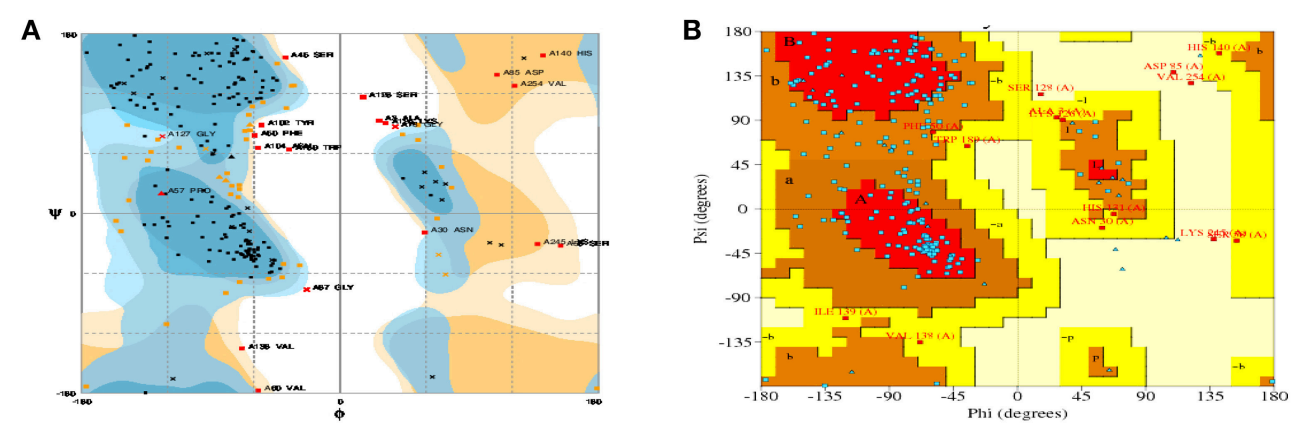

FIGURE 3 | Ramachandran plots for the predicted 3D structure of CHAP-amidase created by RAMPAGE (A) and PDBsum (B). Plot statistics indicate the number of residues in favored regions: 192 (74.4\%), the number of residues in allowed regions: 46 (17.8\%), and the number of residues in outlier regions: 20 (7.8\%).
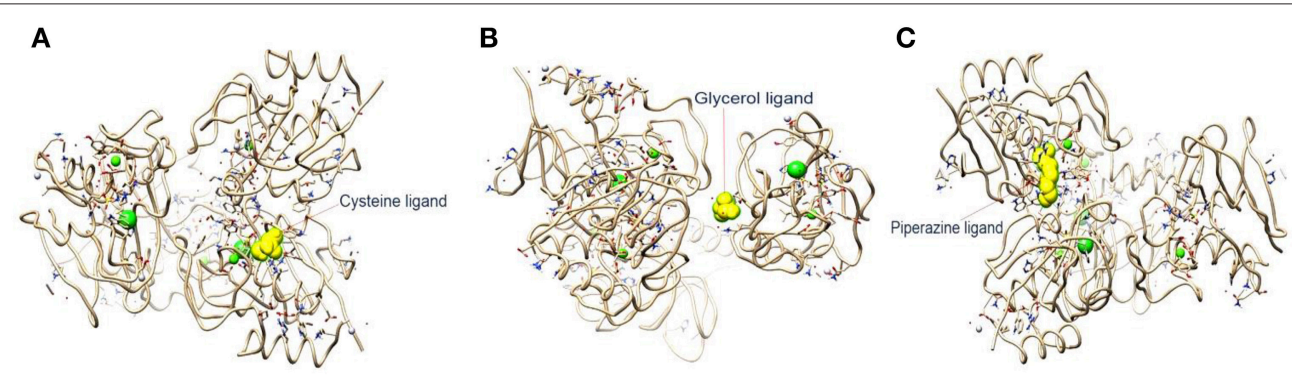

FIGURE 4 | (A) 4ct3/cysteine binding energy $=-150.67 \mathrm{~kJ} / \mathrm{mol}$. (B) 4ct3/glycerol binding energy $=-129.83 \mathrm{~kJ} / \mathrm{mol}$. (C) 4ct3/piperazine binding energy $=-228.66$ $\mathrm{kJ} / \mathrm{mol}$.

786 bp band confirmed accuracy of the cloning of CHAPamidase gene into the vector (Figure 5A). Finally, the construct was sequenced (GenBank accession number: BankIt2010168 Chimeric KY967619).

\section{Protein Expression}

To analyze protein expression, a typical induction experiment was conducted based on comparing the protein profiles of cell lysates obtained from non-induced and induced bacterial cultures (Figure 5B). The results indicated that IPTG can induce the desired expression of CHAPamidase $(\sim 29.5 \mathrm{kDa})$. The overexpressed recombinant protein was identified in the lysate by western blot analysis (Figure 5C).

\section{Purification of CHAP-Amidase Protein}

The detection of protein band $(\sim 29.5 \mathrm{kDa})$ confirmed the purification of CHAP-amidase (Figure 5D). Our procedure led to the purification of $8-12 \mathrm{mg} / \mathrm{L}$ of protein in induced $E$. coli culture.

\section{Lytic Activity of Purified CHAP-Amidase}

Our results demonstrated that the purified CHAP-amidase has antibacterial activity against $\mathrm{MRSA}_{252}$. The inhibition zone of MRSA $_{252}$ growth was detected by disks saturated with different 

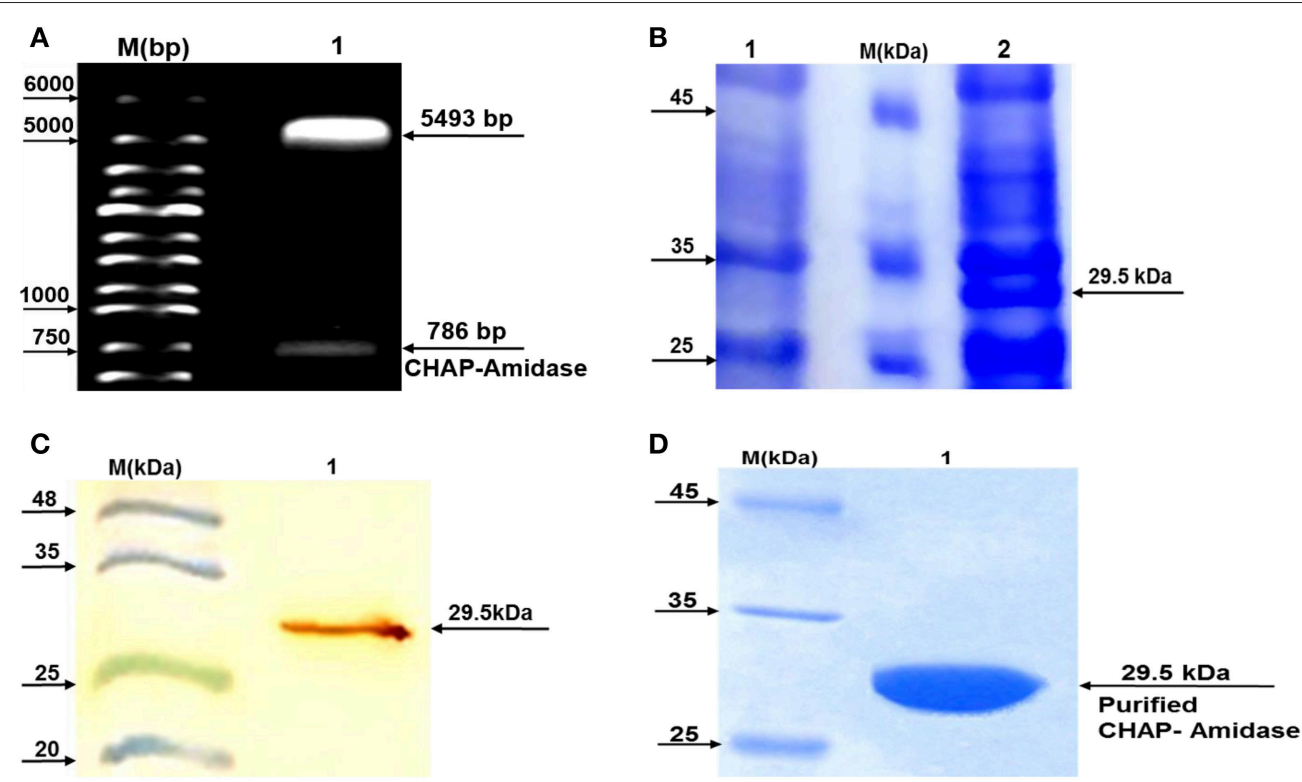

FIGURE 5 | Analysis of LysK-CHAP sequence by agarose gel electrophoresis and analysis of protein expression by SDS-PAGE and western blotting. (A) Lane 1: pET-22b/CHAP-amidase plasmid double digested by Ncol and Hindlll restriction enzymes. Lane M: Molecular size marker (1 kb ladder). Arrows indicate the position of DNA fragments. The presence of a $786 \mathrm{bp}$ fragment confirms the accuracy of the cloning of LysK-b/CHAP-amidase gene into pET-22 vector. (B) Expression analysis of CHAP-amidase derived from the soluble phase of E. coli cell lysate, by SDS-PAGE (10\%). Lane 1: Bacterial lysate before induction by IPTG, M: Molecular weight markers (Fermentas Company), Lane 2: Bacterial lysate after induction by IPTG. (C) Western blot analysis of the expressed CHAP-amidase protein reacted with anti-His tag mAb. M: Pre-stained protein molecular weight markers, Lane 1: CHAP-amidase-expressing bacterial lysate. The arrow indicates the position of the overexpressed CHAP-amidase recombinant protein. (D) Purification of CHAP-amidase; M: Protein marker, 1: Purified protein.

concentrations of CHAP-amidase $(1,0.5$, and $0.1 \mu \mathrm{g} / \mu \mathrm{L})$. This observation was in accordance with the lytic activity of standard purified protein. However, a significant halo, which is caused by bacterial lysis, was not observed at the concentration of $0.05 \mu \mathrm{g} / \mu \mathrm{L}$ (Supplementary Figure 3).

\section{Thermal and pH Stability}

There was not observed any significant alteration in the activity of CHAP-amidase under different temperatures, ranging from 5 to $60^{\circ} \mathrm{C}$, for $15 \mathrm{~min}$. Our findings indicated that the ideal activity of lysin occurs at $15-20^{\circ} \mathrm{C}$ (Figure 6A). During $40-\mathrm{h}$ incubation at $37^{\circ} \mathrm{C}$, the protein retained its activity; however, it was deactivated after 2 days. The lysin protein remained active for 1 month and 1 year when stored at $4^{\circ} \mathrm{C}$ and $-20^{\circ} \mathrm{C}$, respectively.

The specific activity of $\mathrm{MRSA}_{252}$, incubated with $1 \mu \mathrm{g} / \mathrm{mL}$ of endolysin, was monitored in different $\mathrm{pH}$ values for $15 \mathrm{~min}$ by spectrophotometry. The optimum activity of CHAP-amidase was at $\mathrm{pH} 8$; but the protein also exhibited favorable activity at $\mathrm{pH}$ values from 6 to 10 (Figure 6B).

\section{$\mathrm{NaCl}$ Tolerance}

Our results demonstrated that decreasing the concentration of $\mathrm{NaCl}$ from 200 to $0 \mathrm{mmol} / \mathrm{L}$ leads to the increase of the enzymatic activity of CHAP-amidase protein. In 300-500 $\mathrm{mmol} / \mathrm{L}$ concentrations of $\mathrm{NaCl}$, the enzymatic activity was considerably reduced and no significant activity of CHAPamidase was detected in $600-700 \mathrm{mmol} / \mathrm{L}$ concentrations (Figure 7).

\section{Effects of Different Concentration of CHAP-Amidase on MRSA ${ }_{252}$ Cells}

Our observations revealed that different concentrations of CHAP-amidase, including 1,5 , and $10 \mu \mathrm{g} / \mathrm{mL}$, can reduce $\mathrm{MRSA}_{252}$ titer from $8 \times 10^{8} \mathrm{CFU} / \mathrm{mL}$ to $1.6 \times 10^{7}$ $\mathrm{CFU} / \mathrm{mL}, 5.1 \times 10^{6} \mathrm{CFU} / \mathrm{mL}$ and $5.1 \times 10^{5} \mathrm{CFU} / \mathrm{mL}$ (3.2 $\log$ reduction), respectively during $50-\mathrm{min}$ incubation at $37^{\circ} \mathrm{C}(P<0.05)$. The results indicated that $1 \mu \mathrm{g} / \mathrm{mL}$ is the lowest concentration of CHAP-amidase that is able to inhibit the growth of $\mathrm{MRSA}_{252}$ cells $(P=0.017)$. Also, we found that lower concentrations do not have significant effects on the reduction of MRSA turbidity (Figure 8). All assays were performed in triplicate, and data are expressed as the mean $\pm \mathrm{SD}$.

\section{Synergistic Interaction between CHAP-Amidase and Vancomycin}

A standard checkerboard broth micro-dilution assay was used to test whether there is a synergistic interaction between CHAPamidase and vancomycin. The MIC of CHAP-amidase for $\mathrm{MRSA}_{252}$ was determined to be $1 \mu \mathrm{g} / \mathrm{mL}$, while the MIC of vancomycin for $\mathrm{MRSA}_{252}$ was shown to be $2 \mu \mathrm{g} / \mathrm{mL}$. The enzyme concentrations were transcribed along the inhibitory line on the microtiter plate to draw isobologram (an $\mathrm{x} / \mathrm{y}$ plot). The highly synergistic interactions were designated to the curve shape for the antibiotic (Figure 9) and were confirmed by the calculation of $\Sigma F I C$, which was equal to 0.375 . 

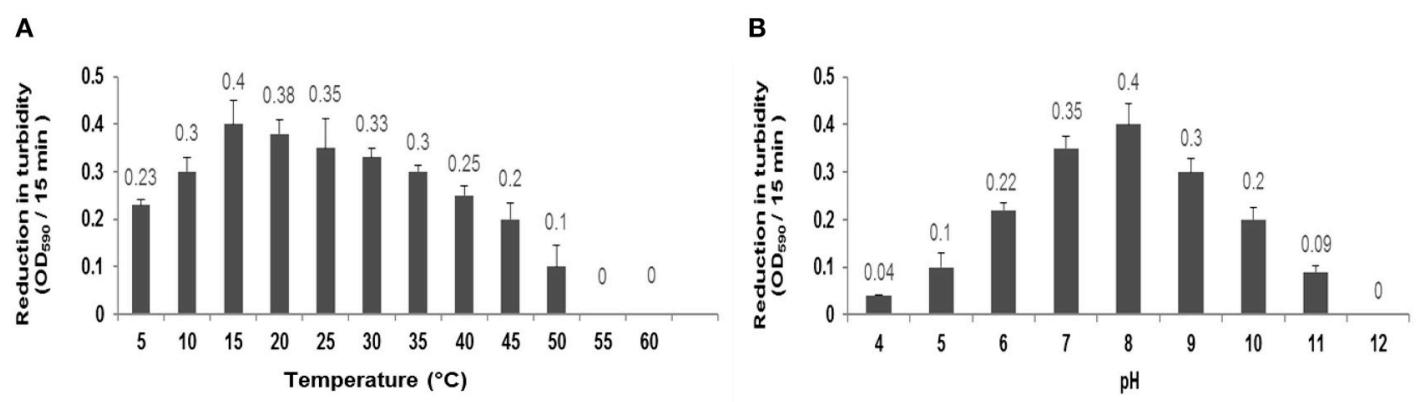

FIGURE 6 | (A) Characterization of CHAP-amidase protein $(1 \mu \mathrm{g} / \mathrm{mL})$ in different temperatures ranging from 5 to $60^{\circ} \mathrm{C}$. (B) Characterization of $\mathrm{CHAP}$-amidase protein in different $\mathrm{pH}$ valus ranging from 4 to 12. Data are expressed as the mean \pm SD.

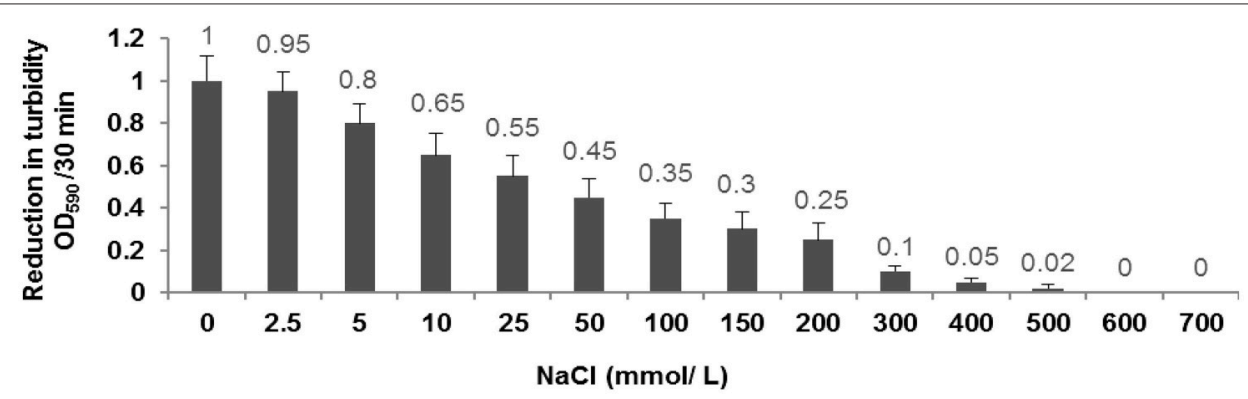

FIGURE 7 | Characterization of the activity of $10 \mu \mathrm{g} / \mathrm{mL}$ CHAP-amidase in different $\mathrm{NaCl}$ concentrations ranging from 0 to $700 \mathrm{mmol} / \mathrm{L}$. Data are expressed as the mean \pm SD.

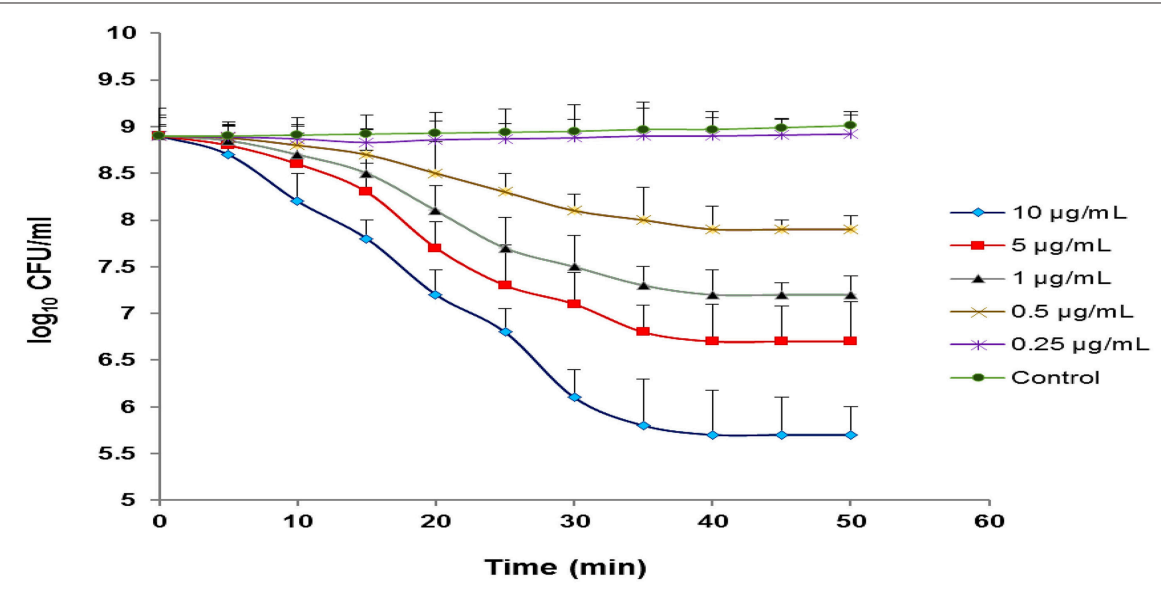

FIGURE 8 | Monitoring the lytic activity of various concentrations of CHAP-amidase against MRSA 252 cells in MHB medium. The graphs show changes in the colony count of $\mathrm{MRSA}_{252}$ cells during a 60-min incubation time. The lysin buffer, rather than the enzyme, was added to negative control. Values are the means of three independent experiments with standard deviation indicated by error bars. Statistical significance was reported as $P<0.05$.

\section{Activity of CHAP-Amidase Endolysin against Other Bacteria}

Our results demonstrated CHAP-amidase endolysin could yield strong turbidity reduction and loss of viable plate counts when used against different species of Staphylococcus and Enterococcus. We observed no significant lytic activity of CHAP-amidase on Gram-negative E. coli and Gram positive Lactococcus lactis (Figure 10).

\section{DISCUSSION}

In the current study, we proposed in silico analysis, expression, purification, and anti-MRSA activity of a novel chimeric protein, which contains CHAP and amidase domains of LysK endolysin. The production of this endolysin has been carried out previously (Horgan et al., 2009; Kashani and Moniri, 2015). However, the current work is the first report on the design and synthesis of 
A

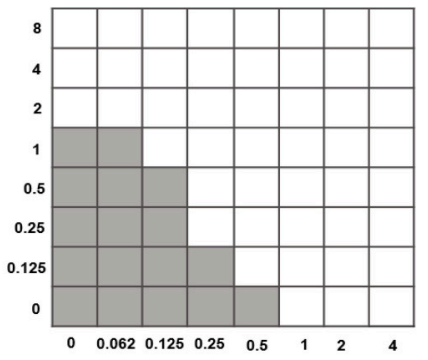

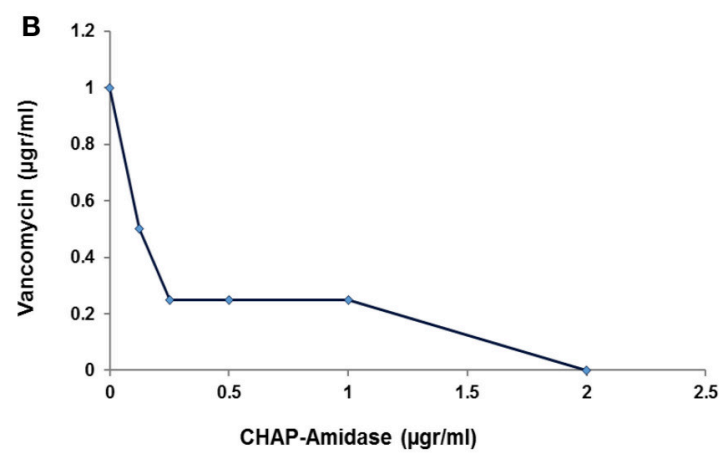

FIGURE 9 | Analysis of synergistic interaction between CHAP-amidase and vancomycin. (A) The checkerboard broth microdilution assay of interaction between CHAP-amidase and vancomycin. (B) Plotting MICs fractional concentrations along the inhibitory line for enzyme or antibiotic to draw an isobologram $(\Sigma F I C<0.5)$.

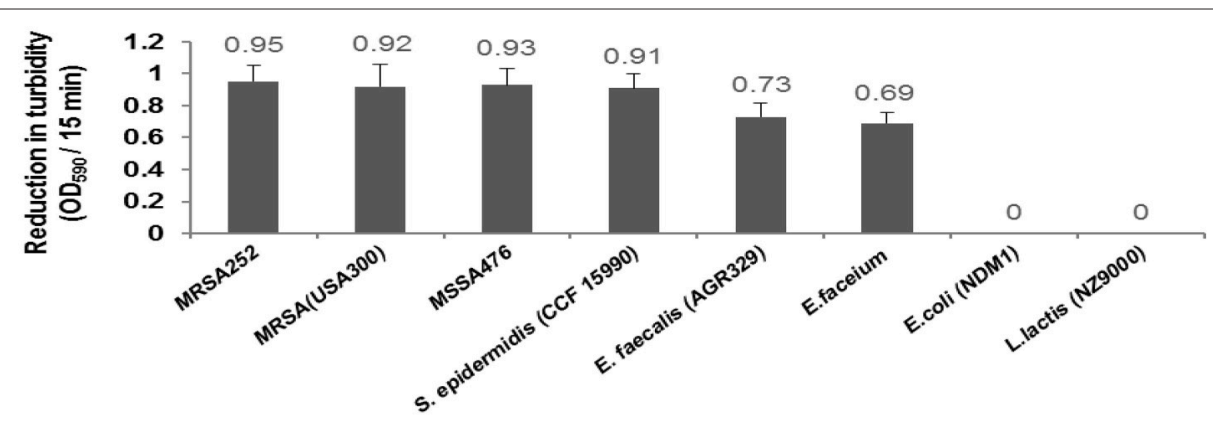

FIGURE 10 | Lytic activity of CHAP-amidase endolysin $(10 \mu \mathrm{g} / \mathrm{mL})$ against different bacterial species. Data are represented as the mean \pm SD.

specific sequence of CHAP-amidase. The construct we designed was able to produce the small enzymatic protein with proper solubility and activity. The $6 \mathrm{x}$ His tag flanked by glycine and serine, which was inserted between the two catalytic domains of the construct, can act as a fusion linker with the ability to prevent spatial interaction of catalytic domains. This linker plays two major roles: poly-His tag sequence may be used for the specific protein detection and GS sequence that is located between CHAP and amidase domains can act as a fusion linker, thereby representing potential to prevent the possibly negative functional interactions between the domains. Glycine and serine residues are known as neutral amino acids and their presence between domains could contribute to the better function of individual domains. Therefore, the linker sequence may lead to an appropriate folding, according to the results obtained from in silico analysis. This new chimeric sequence, which consists of 260 amino acids, was successfully produced as a soluble protein. Suitability of the designed protein sequence was analyzed and verified by bioinformatic approaches. The prediction of secondary and tertiary structures of the protein reinforced the important role played by GS/6xHis/GS linker in the design of bifunctional CHAP-amidase protein. Furthermore, Ramachandran plots analyses provided support for the suitability and sustainability of constructed models in which more than $90 \%$ of residues were in favored and sterically-allowed regions. These data offer convincing evidence for the protein functionality.
We predicted the binding energy of piperazine, cysteine, and glycerol to CHAP-amidase by using bioinformatics method. The results of our analyses indicated that piperazine and cysteine bind stronger than glycerol to CAHP-amidase. Recent studies have revealed the molecular and crystal structures of CHAP-amidase, as well as some ligands related to this protein (Sanz-Gaitero et al., 2014). Of note, a number of studies have shown that the activity of some antibacterial agents may be enhanced when combined with piperazine and cysteine derivatives (Jack et al., 1995; Andersson and MacGowan, 2003; Nowakowska, 2007).

The recombinant lysins of $S$. aureus have been reported to yield low expression and insolubility when produced in a heterologous host (O'flaherty et al., 2005). However, the chimeric versions of these lysins have exhibited higher expression and activity (Becker et al., 2009; Manoharadas et al., 2009; Daniel et al., 2010). To solve the problem of insolubility, we employed pET vectors containing the N-terminal pelB secretion signal. The use of this signal sequence is considered an ideal approach to direct protein expression to the E. coli periplasm (Yoon et al., 2010). Disulfide oxidoreductases and isomerases, which are located in the E. coli periplasm, catalyze the proper folding of soluble proteins. This makes the periplasm an appropriate place for the expression of specific therapeutic proteins (Berkmen, 2012). Previous studies have indicated that the exploitation of pET-21 vector may lead to the production of inclusion bodies inside the cytoplasmic area (Sass and Bierbaum, 2007; Abaev 
et al., 2013). Based on this, we used pET-22b vector for the cloning and expression of LysK-CHAP/amidase. PelB leader sequence in $\mathrm{pET}-22 \mathrm{~b}$ vector directs protein secretion to the periplasmic area and also prevents the formation of inclusion bodies in the cytosol, thereby leading to higher expression of soluble proteins. As shown in the results of SDS-PAGE (Figure 5B), we obtained significant protein expression from the soluble phase of $E$. coli lysate. Increased solubility may enhance the activity and improve the function of proteins.

The purified protein indicated lytic inhibitory zone against $\mathrm{MRSA}_{252}$ at different concentrations. This finding highlights the antibacterial activity of this chimeric endolysin. The investigation of activity retention strongly suggested that the protein maintains proper folding and is stable under a diverse range of temperatures from 5 to $50^{\circ} \mathrm{C}$. Also, tolerating different $\mathrm{pH}$ values gives the protein a specific active state. Although, the protein remained active at various salt concentrations, it showed the highest activity in the absence of $\mathrm{NaCl}$. The results of the current study also highlighted that our recombinant endolysin shows more potent activity (at 10 and $5 \mu \mathrm{g} / \mathrm{mL}$ concentration) against $\mathrm{MRSA}_{252}$ compared with previously studied endolysin constructs (Becker et al., 2009; Fernandes et al., 2012; Proença et al., 2012).

Our in vitro studies demonstrated the presence of a synergistic interaction between chimeric CHAP-amidase and vancomycin as a commonly used antibiotic to treat staphylococcal infections (Daniel et al., 2010). Isobolographic analysis confirmed this synergistic effect against $\mathrm{MRSA}_{252}$ strain with FIC Index of 0.39 . This finding is consistent with previous studies that have indicated a synergistic interplay between some regular antibiotics and chimeric endolysins (Manoharadas et al., 2009; Daniel et al., 2010). Formerly, it has been revealed that native LysK exhibits strong lytic activity against a wide range of staphylococcal species, but it does not show any lytic activity against other bacterial groups (O'Flaherty et al., 2005). In our work, CHAP-amidase presented potent activity against vancomycin-resistant species of Enterococcus wherein the colony counts of Enterococcus faecalis and Enterococcus faecium reduced from $8 \times 10^{8}$ to about 3 $\times 10^{8} \mathrm{CFU} / \mathrm{mL}$ within a $15-\mathrm{min}$ incubation at $37^{\circ} \mathrm{C}$. The endolysin we produced did not show significant antibacterial activity against multi-drug resistant $E$. coli as a representative of Gram-negative bacteria and Lactococcus lactis as a prominent probiotic bacterium. Due to rapid activity and high specificity, the chimeric endolysin obtained in our study could have important implications for the treatment of bacterial infections.

\section{CONCLUSION}

The results of in silico design and analyses suggested the new arrangement of functional CHAP-amidase domains. The purified

\section{REFERENCES}

Abaev, I., Foster-Frey, J., Korobova, O., Shishkova, N., Kiseleva, N., Kopylov, P., et al (2013). Staphylococcal phage 2638A endolysin is lytic for Staphylococcus aureus and harbors an inter-lytic-domain secondary translational start site. Appl. Microbiol. Biotechnol. 97, 3449-3456. doi: 10.1007/s00253-012-4252-4 chimeric protein presented optimal characteristics and specific activity under different thermal, $\mathrm{pH}$ and saline conditions. We observed significant antibacterial activity of endolysin against methicillin-resistant Staphylococcus aureus, also the evidence of a synergism between CHAP-amidase and vancomycin suggests the possibility to use lower doses of vancomycin against pathogenic $S$. aureus strains. Moreover, we found antibacterial activity of endolysin against some antibiotic-resistant bacteria. All of these findings favor the notion that the chimeric endolysin produced in our work may offer promise for the development of an efficient therapeutic and antimicrobial agent in the future. However, further investigation is required to provide more evidence on different aspects of the antibacterial activity of this endolysin.

\section{ETHICS STATEMENT}

Ethical Responsibilities of Authors: This paper is our original unpublished work and it has not been submitted to any other journal for reviews.

Compliance with Ethical Standards: This article does not contain any studies with human participants or animals performed by any of the authors.

\section{AUTHOR CONTRIBUTIONS}

$\mathrm{RM}$ and $\mathrm{HH}$ have conducted the research work. HH and YD were written the manuscript. $\mathrm{HH}$ and $\mathrm{HF}$ were analyzed the data.

\section{ACKNOWLEDGMENTS}

The results described in this paper are part of a Ph.D. thesis. The present work was financially supported by grant No. 94127 from Kashan University of Medical Sciences, Kashan, Iran, and grant No. 95821732 from Iran National Science Foundation. We also thank Deputy of Research and Technology, Ministry of Health and Medical Education of Iran for research grant support. The authors would like to thank Dr. Keivan Akhtari (Department of Physics, University of Kurdistan, Sanandaj, Iran) for his helps in conducting bioinformatic analyses. Our sincere gratitude also goes to Dr. Mathias Schmelcher (Institute of Food, Nutrition and Health, ETH Zurich, Zurich, Switzerland) for his scientific comments and suggestions.

\section{SUPPLEMENTARY MATERIAL}

The Supplementary Material for this article can be found online at: http://journal.frontiersin.org/article/10.3389/fcimb. 2017.00290/full\#supplementary-material

Achberger, A. M., Brox, T. I., Skidmore, M. L., and Christner, B. C. (2011) Expression and partial characterization of an ice-binding protein from a bacterium isolated at a depth of 3,519 $\mathrm{m}$ in the vostok ice core, antarctica. Front. Microbiol. 2:255. doi: 10.3389/fmicb.2011.00255

Andersson, M. I., and MacGowan, A. P. (2003). Development of the quinolones. J. Antimicrob. Chemother. 51, 1-11. doi: 10.1093/jac/dkg212 
Anju, S., Kumar, N. S., Krishnakumar, B., and Kumar, B. D. (2015). Synergistic combination of violacein and azoles that leads to enhanced killing of major human pathogenic dermatophytic fungi Trichophyton rubrum. Front. Cell. Infect. Microbiol. 5:57. doi: 10.3389/fcimb.2015.00057

Bassetti, M., Baguneid, M., Bouza, E., Dryden, M., Nathwani, D., and Wilcox, M. (2014). European perspective and update on the management of complicated skin and soft tissue infections due to methicillin-resistant Staphylococcus aureus after more than 10 years of experience with linezolid. Clin. Microbiol. Infect. 20, 3-18. doi: 10.1111/1469-0691.12463

Becker, S. C., Dong, S., Baker, J. R., Foster-Frey, J., Pritchard, D. G., and Donovan, D. M. (2009). LysK CHAP endopeptidase domain is required for lysis of live staphylococcal cells. FEMS Microbiol. Lett. 294, 52-60. doi: 10.1111/j.1574-6968.2009.01541.x

Berkmen, M. (2012). Production of disulfide-bonded proteins in Escherichia coli. Protein Expr. Purif. 82, 240-251. doi: 10.1016/j.pep.2011.10.009

Briers, Y., Schmelcher, M., Loessner, M. J., Hendrix, J., Engelborghs, Y., Volckaert, G., et al. (2009). The high-affinity peptidoglycan binding domain of Pseudomonas phage endolysin KZ144. Biochem. Biophys. Res. Commun. 383, 187-191. doi: 10.1016/j.bbrc.2009.03.161

Cheng, Q., and Fischetti, V. A. (2007). Mutagenesis of a bacteriophage lytic enzyme PlyGBS significantly increases its antibacterial activity against group B streptococci. Appl. Microbiol. Biotechnol. 74, 1284-1291. doi: 10.1007/s00253-006-0771-1

Cheng, X., Zhang, X., Pflugrath, J. W., and Studier, F. W. (1994). The structure of bacteriophage T7 lysozyme, a zinc amidase and an inhibitor of T7 RNA polymerase. Proc. Natl. Acad. Sci. U.S.A. 91, 4034-4038. doi: 10.1073/pnas.91.9.4034

Daniel, A., Euler, C., Collin, M., Chahales, P., Gorelick, K. J., and Fischetti, V. A. (2010). Synergism between a novel chimeric lysin and oxacillin protects against infection by methicillin-resistant Staphylococcus aureus. Antimicrob. Agents Chemother. 54, 1603-1612. doi: 10.1128/AAC.01625-09

De Lencastre, H., Oliveira, D., and Tomasz, A. (2007). Antibiotic resistant Staphylococcus aureus: a paradigm of adaptive power. Curr. Opin. Microbiol. 10, 428-435. doi: 10.1016/j.mib.2007.08.003

Donovan, D. M., Lardeo, M., and Foster-Frey, J. (2006). Lysis of staphylococcal mastitis pathogens by bacteriophage phi11 endolysin. FEMS Microbiol. Lett. 265, 133-139. doi: 10.1111/j.1574-6968.2006.00483.x

Entenza, J., Loeffler, J., Grandgirard, D., Fischetti, V., and Moreillon, P. (2005). Therapeutic effects of bacteriophage Cpl-1 lysin against Streptococcus pneumoniae endocarditis in rats. Antimicrob. Agents Chemother. 49, 4789-4792. doi: 10.1128/AAC.49.11.4789-4792.2005

Fahimi, H., Allahyari, H., Hassan, Z. M., and Sadeghizadeh, M. (2014). Dengue virus type- 3 envelope protein domain III; expression and immunogenicity. Iran. J. Basic Med. Sci. 17, 836-843. doi: 10.22038/ijbms.2014.3710

Fenton, M., Casey, P. G., Hill, C., Gahan, C. G., McAuliffe, O., O'Mahony, J. et al. (2010). The truncated phage lysin CHAPk eliminates Staphylococcus aureus in the nares of mice. Bioeng. Bugs 1, 404-407. doi: 10.4161/bbug.1.6.13422

Fenton, M., Cooney, J. C., Ross, R. P., Sleator, R. D., McAuliffe, O., O’Mahony, J., et al. (2011a). In silico modeling of the staphylococcal bacteriophage-derived peptidase CHAPK. Bacteriophage 1, 198-206. doi: 10.4161/bact.1.4.18245

Fenton, M., Ross, R., McAuliffe, O., O'Mahony, J., and Coffey, A. (2011b). Characterization of the staphylococcal bacteriophage lysin CHAPK. J. Appl. Microbiol. 111, 1025-1035. doi: 10.1111/j.1365-2672.2011.05119.x

Ferdosian, M., Khatami, M. R., Malekshahi, Z. V., Mohammadi, A., Kashani, H. H., and Shooshtari, M. B. (2015). Identification of immunotopes against Mycobacterium leprae as immune targets using $\mathrm{PhDTm}-12$ mer phage display peptide library. Trop. J. Pharm. Res. 14, 1153-1159. doi: 10.4314/tjpr. v14i7.5

Fernandes, S., Proença, D., Cantante, C., Silva, F. A., Leandro, C., Lourenço, S., et al. (2012). Novel chimerical endolysins with broad antimicrobial activity against methicillin-resistant Staphylococcus aureus. Microb. Drug Resist. 18, 333-343. doi: $10.1089 / \mathrm{mdr} .2012 .0025$

Fischetti, V. A. (2010). Bacteriophage endolysins: a novel anti-infective to control Gram-positive pathogens. Int. J. Med. Microbiol. 300, 357-362. doi: 10.1016/j.ijmm.2010.04.002

Horgan, M., O'Flynn, G., Garry, J., Cooney, J., Coffey, A., Fitzgerald, G. F., et al. (2009). Phage lysin LysK can be truncated to its CHAP domain and retain lytic activity against live antibiotic-resistant staphylococci. Appl. Environ. Microbiol. 75, 872-874. doi: 10.1128/AEM.01831-08
Hosseini, E. S., Moniri, R., Goli, Y. D., and Kashani, H. H. (2016). Purification of antibacterial CHAPK protein using a self-cleaving fusion tag and its activity against methicillin-resistant Staphylococcus aureus. Probiotics Antimicrob. Proteins 8, 202-210. doi: 10.1007/s12602-016-9236-8

Jack, R. W., Tagg, J. R., and Ray, B. (1995). Bacteriocins of gram-positive bacteria. Microbiol. Rev. 59, 171-200.

Jalali, H. K., Salamatzadeh, A., Jalali, A. K., Kashani, H. H., Asbchin, S. A., and Issazadeh, K. (2016). Antagonistic Activity of Nocardia brasiliensis PTCC 1422 Against Isolated Enterobacteriaceae from Urinary Tract Infections. Probiotics Antimicrob. Proteins 8, 41-45. doi: 10.1007/s12602-016-9207-0

Jun, S. Y., Jung, G. M., Yoon, S. J., Oh, M.-D., Choi, Y.-J., Lee, W. J., et al. (2013). Antibacterial properties of a pre-formulated recombinant phage endolysin, SAL-1. Int. J. Antimicrob. Agents 41, 156-161. doi: 10.1016/j.ijantimicag.2012.10.011

Kashani, H. H., and Moniri, R. (2015). Expression of recombinant pET22bLysK-cysteine/histidine-dependent amidohydrolase/peptidase bacteriophage therapeutic protein in Escherichia coli BL21 (DE3). Osong Public Health Res. Perspect. 6, 256-260. doi: 10.1016/j.phrp.2015.08.001

Kashani, H. H., Moshkdanian, G., Atlasi, M. A., Taherian, A. A., Naderian, H., and Nikzad, H. (2013). Expression of galectin-3 as a testis inflammatory marker in vasectomised mice. Cell J. 15, 11-18.

Kelley, L. A., Mezulis, S., Yates, C. M., Wass, M. N., and Sternberg, M. J. (2015). The Phyre2 web portal for protein modeling, prediction and analysis. Nat. Protoc. 10, 845-858. doi: 10.1038/nprot.2015.053

Kusuma, C. M., and Kokai-Kun, J. F. (2005). Comparison of four methods for determining lysostaphin susceptibility of various strains of Staphylococcus aureus. Antimicrob. Agents Chemother. 49, 3256-3263. doi: 10.1128/AAC.49.8.3256-3263.2005

Loessner, M. J. (2005). Bacteriophage endolysins-current state of research and applications. Curr. Opin. Microbiol. 8, 480-487. doi: 10.1016/j.mib.2005.06.002

Loessner, M. J., Kramer, K., Ebel, F., and Scherer, S. (2002). C-terminal domains of Listeria monocytogenes bacteriophage murein hydrolases determine specific recognition and high-affinity binding to bacterial cell wall carbohydrates. Mol. Microbiol. 44, 335-349. doi: 10.1046/j.1365-2958.2002.02889.x

Lovell, S. C., Davis, I. W., Arendall, W. B., de Bakker, P. I., Word, J. M., Prisant, M. G., et al. (2003). Structure validation by $\mathrm{C} \alpha$ geometry: $\Phi, \psi$ and $\mathrm{C} \beta$ deviation. Proteins 50, 437-450. doi: 10.1002/prot.10286

Low, K. O., Mahadi, N. M., and Illias, R. M. (2013). Optimisation of signal peptide for recombinant protein secretion in bacterial hosts. Appl. Microbiol. Biotechnol. 97, 3811-3826. doi: 10.1007/s00253-013-4831-z

Low, L. Y., Yang, C., Perego, M., Osterman, A., and Liddington, R. C. (2005). Structure and lytic activity of a Bacillus anthracis prophage endolysin. J. Biol. Chem. 280, 35433-35439. doi: 10.1074/jbc.M502723200

Magi, G., Marini, E., and Facinelli, B. (2015). Antimicrobial activity of essential oils and carvacrol, and synergy of carvacrol and erythromycin, against clinical, erythromycin-resistant Group A Streptococci. Front. Microbiol. 6:165. doi: 10.3389/fmicb.2015.00165

Magiorakos, A. P., Srinivasan, A., Carey, R., Carmeli, Y., Falagas, M., Giske, C., et al. (2012). Multidrug-resistant, extensively drug-resistant and pandrugresistant bacteria: an international expert proposal for interim standard definitions for acquired resistance. Clin. Microbiol. Infect. 18, 268-281. doi: 10.1111/j.1469-0691.2011.03570.x

Manoharadas, S., Witte, A., and Bläsi, U. (2009). Antimicrobial activity of a chimeric enzybiotic towards Staphylococcus aureus. J. Biotechnol. 139, 118-123. doi: 10.1016/j.jbiotec.2008.09.003

Martínez-Alonso, M., González-Montalbán, N., García-Fruitós, E., and Villaverde, A. (2009). Learning about protein solubility from bacterial inclusion bodies. Microb. Cell Fact. 8:4. doi: 10.1186/1475-2859-8-4

McCullers, J. A., Karlstrom, A., Iverson, A. R., Loeffler, J. M., and Fischetti, V. A. (2007). Novel strategy to prevent otitis media caused by colonizing Streptococcus pneumoniae. PLoS Pathog. 3:e28. doi: 10.1371/journal.ppat.0030028

Nelson, D., Loomis, L., and Fischetti, V. A. (2001). Prevention and elimination of upper respiratory colonization of mice by group A streptococci by using a bacteriophage lytic enzyme. Proc. Natl. Acad. Sci. U.SA. 98, 4107-4112. doi: $10.1073 /$ pnas. 061038398

Nelson, D., Schuch, R., Chahales, P., Zhu, S., and Fischetti, V. A. (2006). PlyC: a multimeric bacteriophage lysin. Proc. Natl. Acad. Sci. U.SA. 103, 10765-10770. doi: $10.1073 /$ pnas. 0604521103 
Nickerson, E. K., West, T. E., Day, N. P., and Peacock, S. J. (2009). Staphylococcus aureus disease and drug resistance in resource-limited countries in south and east Asia. Lancet Infect. Dis. 9, 130-135. doi: 10.1016/S1473-3099(09)7 0022-2

Nowakowska, Z. (2007). A review of anti-infective and anti-inflammatory chalcones. Eur. J. Med. Chem. 42, 125-137. doi: 10.1016/j.ejmech.2006.09.019

Obeso, J. M., Martínez, B., Rodríguez, A., and García, P. (2008). Lytic activity of the recombinant staphylococcal bacteriophage $\Phi \mathrm{H} 5$ endolysin active against Staphylococcus aureus in milk. Int. J. Food Microbiol. 128, 212-218. doi: 10.1016/j.ijfoodmicro.2008.08.010

Odds, F. C. (2003). Synergy, antagonism, and what the chequerboard puts between them. J. Antimicrob. Chemother. 52, 1-1. doi: 10.1093/jac/dkg301

O'flaherty, S., Coffey, A., Meaney, W., Fitzgerald, G., and Ross, R. (2005). The recombinant phage lysin LysK has a broad spectrum of lytic activity against clinically relevant staphylococci, including methicillin-resistant Staphylococcus aureus. J. Bacteriol. 187, 7161-7164. doi: 10.1128/JB.187.20.7161-7164.2005

O’Flaherty, S., Ross, R., Flynn, J., Meaney, W., Fitzgerald, G., and Coffey, A. (2005). Isolation and characterization of two anti-staphylococcal bacteriophages specific for pathogenic Staphylococcus aureus associated with bovine infections. Lett. Appl. Microbiol. 41, 482-486. doi: 10.1111/j.1472-765X.2005.01781.x

Oliveira, H., Boas, D. V., Mesnage, S., Kluskens, L. D., Lavigne, R., Sillankorva, S., et al. (2016). Structural and enzymatic characterization of ABgp46, a novel phage endolysin with broad anti-Gram-negative bacterial activity. Front. Microbiol. 7:208. doi: 10.3389/fmicb.2016.00208

Pogue, J., Kaye, K., Cohen, D., and Marchaim, D. (2015). Appropriate antimicrobial therapy in the era of multidrug-resistant human pathogens. Clin. Microbiol. Infect. 21, 302-312. doi: 10.1016/j.cmi.2014.12.025

Proença, D., Fernandes, S., Leandro, C., Silva, F. A., Santos, S., Lopes, F., et al. (2012). Phage endolysins with broad antimicrobial activity against Enterococcus faecalis clinical strains. Microb. Drug Resist. 18, 322-332. doi: $10.1089 / \mathrm{mdr} .2012 .0024$

Rashel, M., Uchiyama, J., Ujihara, T., Uehara, Y., Kuramoto, S., Sugihara, S., et al. (2007). Efficient elimination of multidrug-resistant Staphylococcus aureus by cloned lysin derived from bacteriophage ФMR11. J. Infect. Dis. 196, 1237-1247. doi: $10.1086 / 521305$

Reich, P. J., Boyle, M. G., Hogan, P. G., Johnson, A. J., Wallace, M. A., Elward, A. M., et al. (2016). Emergence of community-associated Methicillin-resistant Staphylococcus aureus strains in the neonatal intensive care unit: an infection prevention and patient Safety Challenge. Clin. Microbiol. Infect. 22, 645.e1-8. doi: 10.1016/j.cmi.2016.04.013

Rinas, U., Hoffmann, F., Betiku, E., Estapé, D., and Marten, S. (2007). Inclusion body anatomy and functioning of chaperone-mediated in vivo inclusion body disassembly during high-level recombinant protein production in Escherichia coli. J. Biotechnol. 127, 244-257. doi: 10.1016/j.jbiotec.2006.07.004

Ritchie, D. W., and Venkatraman, V. (2010). Ultra-fast FFT protein docking on graphics processors. Bioinformatics 26, 2398-2405. doi: 10.1093/bioinformatics/btq444

Rosano, G. L., and Ceccarelli, E. A. (2014). Recombinant protein expression in Escherichia coli: advances and challenges. Front. Microbiol. 5:172. doi: $10.3389 /$ fmicb. 2014.00172
Roy, A., Kucukural, A., and Zhang, Y. (2010). I-TASSER: a unified platform for automated protein structure and function prediction. Nat. Protoc. 5, 725-738. doi: 10.1038/nprot.2010.5

Salge, T. O., Vera, A., Antons, D., and Cimiotti, J. P. (2016). Fighting MRSA infections in hospital care: how organizational factors matter. Health Serv. Res. 52, 959-983. doi: 10.1111/1475-6773.12521

Sanz-Gaitero, M., Keary, R., Garcia-Doval, C., Coffey, A., and van Raaij, M. J. (2014). Crystal structure of the lytic CHAP $\mathrm{K}$ domain of the endolysin LysK from Staphylococcus aureus bacteriophage K. Virol. J. 11:1. doi: 10.1186/1743-422X-11-133

Sass, P., and Bierbaum, G. (2007). Lytic activity of recombinant bacteriophage $\varphi 11$ and $\Phi 12$ endolysins on whole cells and biofilms of Staphylococcus aureus. Appl. Environ. Microbiol. 73, 347-352. doi: 10.1128/AEM.01616-06

Schmelcher, M., and Loessner, M. J. (2016). Bacteriophage endolysins: applications for food safety. Curr. Opin. Biotechnol. 37, 76-87. doi: 10.1016/j.copbio.2015.10.005

Schuch, R., Nelson, D., and Fischetti, V. A. (2002). A bacteriolytic agent that detects and kills Bacillus anthracis. Nature 418, 884-889. doi: 10.1038/nature01026

Sharif, A., Kashani, H. H., Nasri, E., Soleimani, Z., and Sharif, M. R. (2017). The role of probiotics in the treatment of dysentery: a randomized double-blind clinical trial. Probiotics Antimicrob. Proteins doi: 10.1007/s12602-017-9271-0. [Epub ahead of print].

Sharif, M. R., Kashani, H. H., Ardakani, A. T., Kheirkhah, D., Tabatabaei, F., and Sharif, A. (2016). The effect of a yeast probiotic on acute diarrhea in children. Probiotics Antimicrob. Proteins 8, 211-214. doi: 10.1007/s12602-016-9221-2

Ventura, S., and Villaverde, A. (2006). Protein quality in bacterial inclusion bodies. Trends Biotechnol. 24, 179-185. doi: 10.1016/j.tibtech.2006.02.007

Yang, J., Yan, R., Roy, A., Xu, D., Poisson, J., and Zhang, Y. (2015). The ITASSER Suite: protein structure and function prediction. Nat. Methods 12, 7-8. doi: $10.1038 /$ nmeth.3213

Yang, J., and Zhang, Y. (2015). I-TASSER server: new development for protein structure and function predictions. Nucleic Acids Res. 43, W174-W181. doi: 10.1093/nar/gkv342

Yoon, S. H., Kim, S. K., and Kim, J. F. (2010). Secretory production of recombinant proteins in Escherichia coli. Recent Pat. Biotechnol. 4, 23-29. doi: 10.2174/187220810790069550

Zhang, Y. (2008). I-TASSER server for protein 3D structure prediction. BMC Bioinformatics 9:40. doi: 10.1186/1471-2105-9-40

Conflict of Interest Statement: The authors declare that the research was conducted in the absence of any commercial or financial relationships that could be construed as a potential conflict of interest.

Copyright (C) 2017 Haddad Kashani, Fahimi, Dasteh Goli and Moniri. This is an open-access article distributed under the terms of the Creative Commons Attribution License (CC BY). The use, distribution or reproduction in other forums is permitted, provided the original author(s) or licensor are credited and that the original publication in this journal is cited, in accordance with accepted academic practice. No use, distribution or reproduction is permitted which does not comply with these terms. 